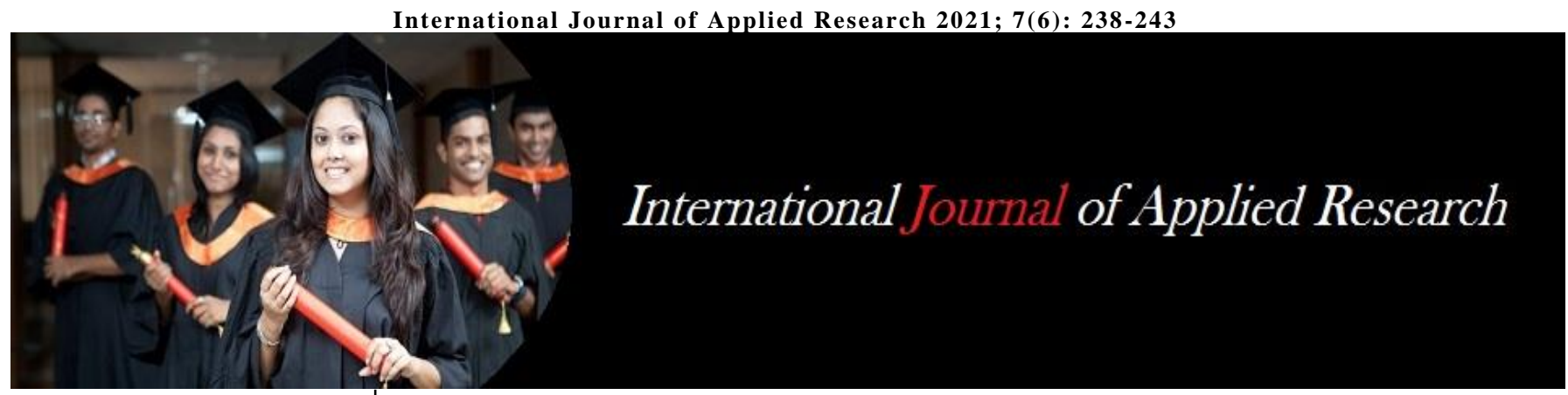

ISSN Print: 2394-7500 ISSN Online: 2394-5869 Impact Factor: 8.4

IJAR 2021; 7(6): 238-243 www.allresearchjournal.com

Received: 13-04-2021 Accepted: 15-05-2021

S Radhathirumalaiarasu Assistant Professor,

Department of Microbiology,

The Standard fireworks

Rajaratnam College for

Women, Sivakasi, Tamil Nadu, India

I Parveen Taj

M.Sc. Student, Department of Microbiology, The Standard fireworks Rajaratnam College for Women, Sivakasi, Tamil Nadu, India
Corresponding Author: S Radhathirumalaiarasu Assistant Professor, Department of Microbiology, The Standard fireworks Rajaratnam College for Women, Sivakasi, Tamil Nadu, India

\section{Novel alkaline protease of Staphylococcus cohnii N3 isolated from poultry farm soil used for silver recovery from waste $X$-ray film}

\section{S Radhathirumalaiarasu and I Parveen Taj}

DOI: https://doi.org/10.22271/allresearch.2021.v7.i6d.8692

\begin{abstract}
Alkaline proteases are one of the most widely used as industrial enzyme recently explored for its effective degrading ability in bioremediation. In the present study alkaline protease producing bacteria was isolated from soil samples collected from waste dumped area in poultry farm. The isolate was identified as Staphylococcus cohnii N3 strain by 16s rRNA sequencing analysis. The effect of pH and temperature on alkaline protease was found that showed maximum activity at $\mathrm{pH} 9$ and at temperature $60^{\circ} \mathrm{C}(162 . \mathrm{U} / \mathrm{ml})$. The isolated S. cohnii N3 was further experimented for silver recovery and gelatin hydrolysis. Gelatin hydrolysis was monitored by measuring increase in turbidity in the hydrolysate. Gelatin layer was stripped completely within $20 \mathrm{~min}$ at $40{ }^{\circ} \mathrm{C}, \mathrm{pH}$ 9. Rate of gelatin hydrolysis increased with increased in time shows complete decolorization of X-ray film proves its suitability for silver recovery.
\end{abstract}

Keywords: alkaline protease, Staphylococcus, silver recovery, X-ray films, gelatin hydrolysis

\section{Introduction}

X-ray films is considered as hazardous waste depends upon the amount of lead aprons and lead dental foil present in the X-ray films are considered as hazardous waste (Galarpe and Leopoldo 2018) ${ }^{[1]}$. Byproduct of X-rays film has lead waste which is held in the topsoil where it can remain for us longer 2000 years. Lead is a deadly neurotoxin is readily pick up by plants, enters our food system and possess threat to environmental and human health (Hossain et al., 2021) ${ }^{[2]}$. The used Xray/photographic films containing black metallic silver spread in gelatin are very rich source for silver recovery. High concentration of silver and compounds containing it led to argyria, which results in a blue-grayish pigmentation of the skin, eyes, and mucous membranes. The fixing and bleaching solution that contains silver thiosulfate with silver cause harmful effect. This waste can be utilized as rich source of silver a valuable noble metal used for many purposes, such in the photographic industry, especially by using X- ray films (Satyanarayana and Chandra, 2020) ${ }^{[3]}$.

The conventional method of directly burning the $\mathrm{X}$-ray films to recover the silver, generates the undesirable foul smell, causes the environmental pollution and polyester film which contains emulsion of silver and the coated gelatin cannot be recovered (Guleria et al., 2018) [4]. Chemical methods use, nitric acid or reagents such as sodium cyanide, $\mathrm{NaOH}$, nitric acid or organic compounds for performing the process of stripping the gelatin- silver (Erku et al., $2019)^{[5]}$. Gelatin layer has cross linked molecules which is hardeners and it is difficult for the usual proteases. After enzymatic hydrolysis silver was recovered either as metallic silver or as silver chloride. Silver chloride can be used to make photographic paper, as pottery glazes, in photochromic lenses, in stained glass manufacture, in bandages and wound healing products. X-ray or photographic films contains $1.5-2 \%(\mathrm{w} / \mathrm{w})$ of silver in its gelatin layers. Alkaline protease has an important role in the recovery of silver from used X-ray films. The enzyme degrades the gelatin layer embedded with silver in X-ray films. The conventional method of burning $\mathrm{X}$-ray films cause environmental pollution. By recycling the photographic wastes $18-20 \%$ of the world's silver requirement is attained (Sharma et al., 2019) ${ }^{[6]}$. 
The protease enzyme forms major group of industrially and academically important enzymes that shares $65 \%$ percent of annual enzyme market. They have a history of applications in food and detergent industries where the alkaline proteases hold the biggest share of the enzyme market worldwide. Alkaline protease constitutes main ingredient of detergents, have applications in leather industry, medical diagnostics, recovery of silver from X-rays, food and feed industry etc. (Sundus et al., 2016) ${ }^{[7]}$.

Enzymes produced from microbial sources are most advantageous comparatively from other sources like animals or vegetables etc. (Varia et al., 2019) ${ }^{[8]}$. Many microbial strains including fungi (Aspergillus flavus, Aspergillus miller, Aspergillus niger and Penicillium griseofulvin; Bacillus sp. (Bacillus licheniformis, Bacillus firmus, Bacillus alcalo, Bacillus subtilis and Bacillus thuringiensis) have investigated earlier and optimized for nutrient sources, $\mathrm{pH}$ and temperature to get maximum protease (Akshatha et al., 2020) ${ }^{[9]}$. Bacillus sp. have wide industrial application and in bioremediation of polluted environment, managing pollutants by detoxification and mineralization. The remediation of recalcitrant pollutants using microbial enzymes is considered environment friendly, cost effective, innovative, and promising (Razzaq et al., 2019) ${ }^{[10]}$. Only few works are available on exploring protease of other microorganisms, hence this work aimed to isolate efficient alkaline protease producing strain from poultry farm waste dumped area. Further the strain was analyzed for gelatin hydrolysis and recovery of silver from used X-ray films.

\section{Materials and Methods}

\subsection{Collection of soil sample}

The soil sample was collected from the nearby surrounding of the poultry farm in Sivakasi from waste dumbed area. Soil was collected below $4-5 \mathrm{~cm}$ depth in sterile container and stored at $4{ }^{\circ} \mathrm{C}$ until performing the further experiments.

\subsection{Isolation and Screening of Proteolytic bacteria}

The soil sample (1g) was serially diluted with the sterile distilled water and spread plated on nutrient agar medium $\left(\mathrm{pH}\right.$ 8) incubated at $37^{\circ} \mathrm{C}$ for $24 \mathrm{~h}$. The isolates were screened using skim milk (1\% w/v) agar plates and incubated at $37^{\circ} \mathrm{C}$ for $48 \mathrm{~h}$.

\subsection{Biochemical and Molecular characterization of selected isolate}

The isolated colonies were examined microscopically and biochemical characteristics were studied such as Indole test, Methyl red and oxidase test. For further identification of selected bacterial strain at species level, 16s rRNA nucleotide sequence analysis were performed at Exonn Biosciences, Vandallur, Tamil Nadu.

\subsection{Protease enzyme assay}

The culture of proteolytic isolate was inoculated in $20 \mathrm{ml}$ of protease production media with the composition of $1 \mathrm{~g}$ casein, $0.2 \mathrm{~g} \mathrm{KH}_{2} \mathrm{PO}_{4}, 0.2 \mathrm{~g} \mathrm{~K}_{2} \mathrm{HPO}_{4}$ and $0.1 \mathrm{~g} \mathrm{MgSO}_{4} .7 \mathrm{H}_{2} \mathrm{O}$ in $100 \mathrm{ml}$ of distilled water and incubated for $48 \mathrm{~h}$ in a rotatory shaker in $200 \mathrm{rpm}$ at temperature of $37^{\circ} \mathrm{C}$. After incubation, the culture was centrifuged at $10,000 \mathrm{rpm}$ for 20 minutes at $4{ }^{\circ} \mathrm{C}$ in the cooling centrifuge and the collected supernatant was used as crude enzyme source for protease assay. For protease assay casein was dissolved in $\mathrm{pH}$ buffer and the reaction mixture containing casein and enzyme solution was incubated for 10 minutes at $37^{\circ} \mathrm{C}$. The reaction was stopped by adding $3 \mathrm{ml}$ of $20 \%$ ice cold trichloroacetic acid and the precipitated proteins were removed by centrifugation. The $0.5 \mathrm{ml}$ of the supernatant was mixed with $2.5 \mathrm{ml}$ of $0.5 \mathrm{M} \mathrm{Na}_{2} \mathrm{CO}_{3}$ and kept for 20 minutes at room temperature. Finally added with the appropriately diluted Folin's phenol reagent. The mixture kept for 10 minutes and the absorbance was measured at $660 \mathrm{~nm}$ against the blank sample. One unit of protease activity was calculated as release of one $\mu \mathrm{g}$ tyrosine per $\mathrm{ml}$ per minute (Sarkar et al., 2013) ${ }^{[11]}$.

\subsection{Effect of pH and temperature on enzyme activity}

The $\mathrm{pH}$ was adjusted using different $\mathrm{pH}$ buffer ranging from 7-11 and all tubes were incubated at $37{ }^{\circ} \mathrm{C}$ for $30 \mathrm{~min}$ and experimented for alkaline protease activity. Effect of temperature was analyzed by maintaining the reaction mix of different tubes at temperature ranging from 30 to $80{ }^{\circ} \mathrm{C}$. All the tubes were incubated for 30 minutes and enzyme activities were determined by standard enzyme assay.

\subsection{Recovery of silver and gelatin hydrolysis}

Used waste X films were washed with distilled water and wipe with cotton impregnated with ethanol. Then washed Xray films was dried in hot air oven for 30 minutes. X- ray film $(1 \mathrm{~g})$ was cut into $2 \times 2 \mathrm{~cm}$ pieces was then incubated with $10 \mathrm{ml}$ of crude protease for different time interval at 40 ${ }^{\circ} \mathrm{C} \mathrm{pH} 9$ in a water bath with the continuous shaking. Turbidity of the reaction mixture hydrolysate increased with the time and when no further increase in turbidity was observed, consider hydrolysis was complete. The progress of hydrolysis that Lowry for turbidity was monitored by measuring the absorbance at $660 \mathrm{~nm}$. Protein released during gelatin hydrolysis was monitored following method of et al. (1951) ${ }^{[12]}$ with bovine serum albumin (BSA) as the standard and used for calculation of percentage of gelatin hydrolysis (Shankar et al., 2010) ${ }^{[13]}$.

\section{Results and Discussions}

\subsection{Screening of alkaline proteolytic bacteria}

Seven bacterial isolates were recovered from the collected soil sample from poultry farm in the nutrient agar plates. Among four isolated bacteria, the strain N3 showed highest protease activity as $105.05 \pm 0.9 \mathrm{U} / \mathrm{ml}$ (Fig. 1). Similarly, total six bacterial colonies were screened and Bacillus sp. GS-P4 produced highest protease activity $(0.0233 \mathrm{U} / \mathrm{ml})$ was isolated from soil samples collected from farm soil, garden soil of BIMTS college campus and oil spilled area of Burhanpur (MP), India (Rupali, 2015) ${ }^{[14]}$. Hamdani et al. (2019) ${ }^{[15]}$ isolated 2 potential proteolytic bacteria from 10 isolates of pig sludge.

\subsection{Identification of alkaline proteolytic bacteria}

Amongst the isolates the strain with increased proteolytic activity was gram positive, non-spore former, negative for indole and oxidase test and positive for methyl red test. The Blast results of sequence 16s rRNA gene observed that the isolate exhibit the similarity to Staphylococcus cohnii. The partial sequence of Staphylococcus cohnii N3 was deposited in GenBank under the accession number is MZ013138. Further the phylogenetic tree was constructed based on the 16 sequencing analysis and Staphylococcus cohnii N3 showed the close relationship with the Staphylococcus cohnii NR03902 (Fig 2). Similarly, among the 12 isolates 
screened from sediment samples protease of Staphylococcus saprophyticus showed the highest protease production $(6.50 \pm 0.03 \mathrm{U} / \mathrm{ml})$ (Uttatree et al., 2018) ${ }^{[16]}$. Among the two different proteolytic isolates found in the soil sample which was collected from adjacent areas of sweetshop dentified as Staphylococcus pasteuri strain produces $1.28 \mathrm{mg} / \mathrm{ml}$ of protein (Chakraborty and Karmakar, 2020) ${ }^{[17] .}$

\subsection{Effect of pH on Protease activity}

Staphylococcus cohnii N3 strain produced the highest proteolytic activity at $\mathrm{pH}$ 9. Above $\mathrm{pH} 9$ the proteolytic activity declined gradually, however retaining $82.3 \%$ of protease activity at $\mathrm{pH} 10$. Hence the optimum $\mathrm{pH}$ for isolate Staphylococcus cohnii N3 strain was found to be $\mathrm{pH}$ 9 with maximum proteolytic activity of $107.3 \pm 0.5 \mathrm{U} / \mathrm{ml}$ in with casein as substrate (Fig 3). Whereas, protease of Geobacillus thermoglucosidasius SKF4 exhibit maximum protease activity at pH 7 to 8 (Suleiman et al., 2020) ${ }^{[18]}$. Bacillus isronensis strain $\mathrm{KD} 3$ produced maximum proteases at $42^{\circ} \mathrm{C}$ and $\mathrm{pH} 7-8$ after $48 \mathrm{~h}$ of the incubation period (Patil and Kurhekar, 2020) ${ }^{[19]}$. Alkaline protease of Bacillus sp. DB14 has maximum activity at $\mathrm{pH} 10.5$ and temperature $60^{\circ} \mathrm{C}$ (Yigit Sat et al., 2020) ${ }^{[20]}$. Alkaline protease produced by Bacillus amyloliquefaciens HM48 showed optimum activity at pH 8 (Mushtaq et al., 2021) [21] and Bacillus stearothermophilus showed increased activity at pH 10 (Karray et al., 2021) ${ }^{[22] .}$

Alkaline protease of Staphylococcus aureus S-2 isolated from Chicken Waste have optimal $\mathrm{pH}$ and temperature at 8.0 and $50{ }^{\circ} \mathrm{C}$ (Akram et al., 2014) ${ }^{[23]}$. Chakrabarty et al. (2018) ${ }^{[24]}$ investigated increased protease activity of isolate Bacillus sp. at neutral and alkaline $\mathrm{pH}$ used for digestion of milk and egg proteins, removal of stains.

\subsection{Effect of temperature on alkaline protease activity}

Proteolytic activity of Staphylococcus cohnii N3 strain increased with raise in temperature correlating with increased casein hydrolysis and showed maximum activity at $60{ }^{\circ} \mathrm{C}(162.3 \pm 0.7)$. It retains $82 \%$ of alkaline protease activity at $80{ }^{\circ} \mathrm{C}$. Hence the optimum temperature for alkaline protease production by isolate Staphylococcus cohnii N3 strain was found to be at $60{ }^{\circ} \mathrm{C}$ (Fig. 4). This result coincides with alkaline protease of Bacillus infantis SKS1 isolated from garden soil that showed increased activity at $60{ }^{\circ} \mathrm{C}$ (Saggu et al., 2017) ${ }^{[25]}$. Gopalakrishnan et al. (2021) ${ }^{[26]}$ observed increase stability of alkaline protease of Endophyte Brevundimonas diminuta VKB1 till $40{ }^{\circ} \mathrm{C}$ and the activity dropdown at $60{ }^{\circ} \mathrm{C}$.

\subsection{Gelatin hydrolysis and Silver recovery}

When the X-ray films were treated with the alkaline protease solution of Staphylococcus cohnii N3, $90 \%$ gelatin hydrolysis was observed at the end of 15 minutes and complete removal was achieved within 20 min shown by decolourized X-ray film (Fig. 5). Similarly, using protease of Bacillus sp. ATP-P5 treated X-ray film 1.5-2\% (w/w) metallic silver (Black in color) were recovered (Kumari et al., 2015) ${ }^{[27]}$. With alkaline protease of Bacillus subtilis NCIM 2724 complete stripping of gelatin occur within 4 to 6 days with crude protease at $37{ }^{\circ} \mathrm{C}$ and $\mathrm{pH} 8$ used for $0.5012 \mathrm{~g}$ recovery of silver (Parpalliwar et al., 2015) ${ }^{[28]}$. AlAbdalall and Al-Khaldi (2016) employed B. subtilis protease for recovery of silver within $30 \mathrm{~min}$ at $50^{\circ} \mathrm{C}$ and

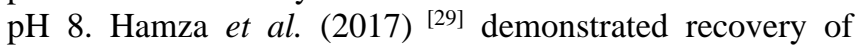
gelatin and silver from waste $\mathrm{X}$-ray film at $\mathrm{pH} 9,40^{\circ} \mathrm{C}$ in 40 min by Bacillus sp. THZ14.

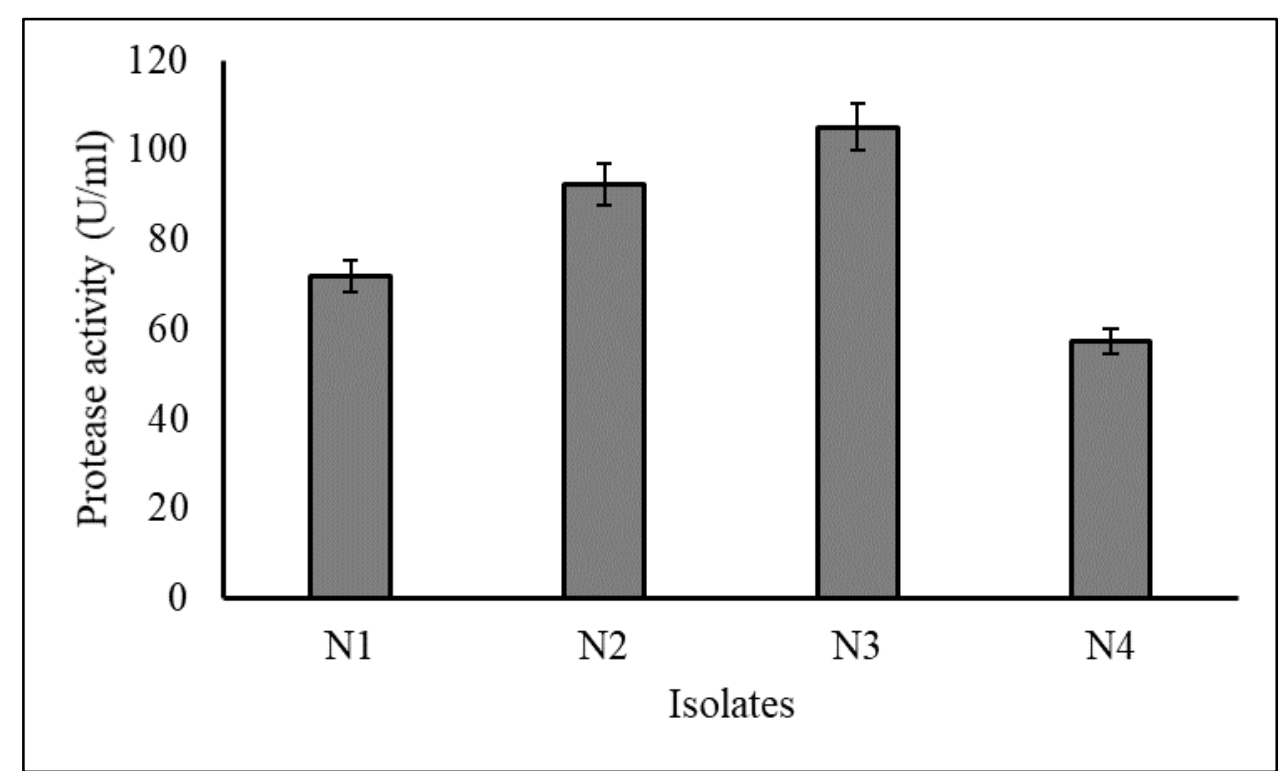

Fig 1: Alkaline protease activity of Isolates from Poultry soil 


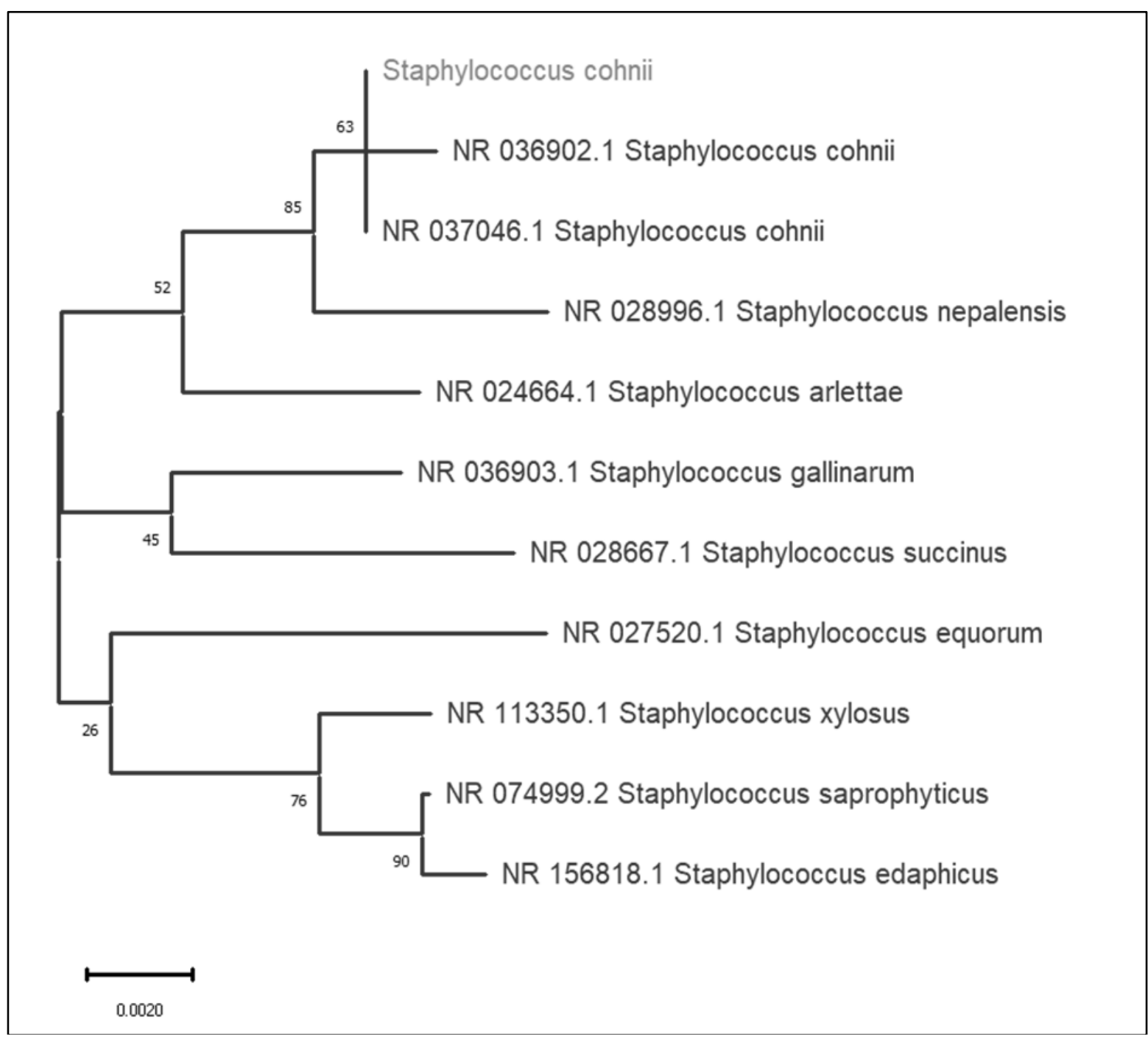

Fig 2: Phylogenetic analysis of identified Staphylococcus cohnii N3

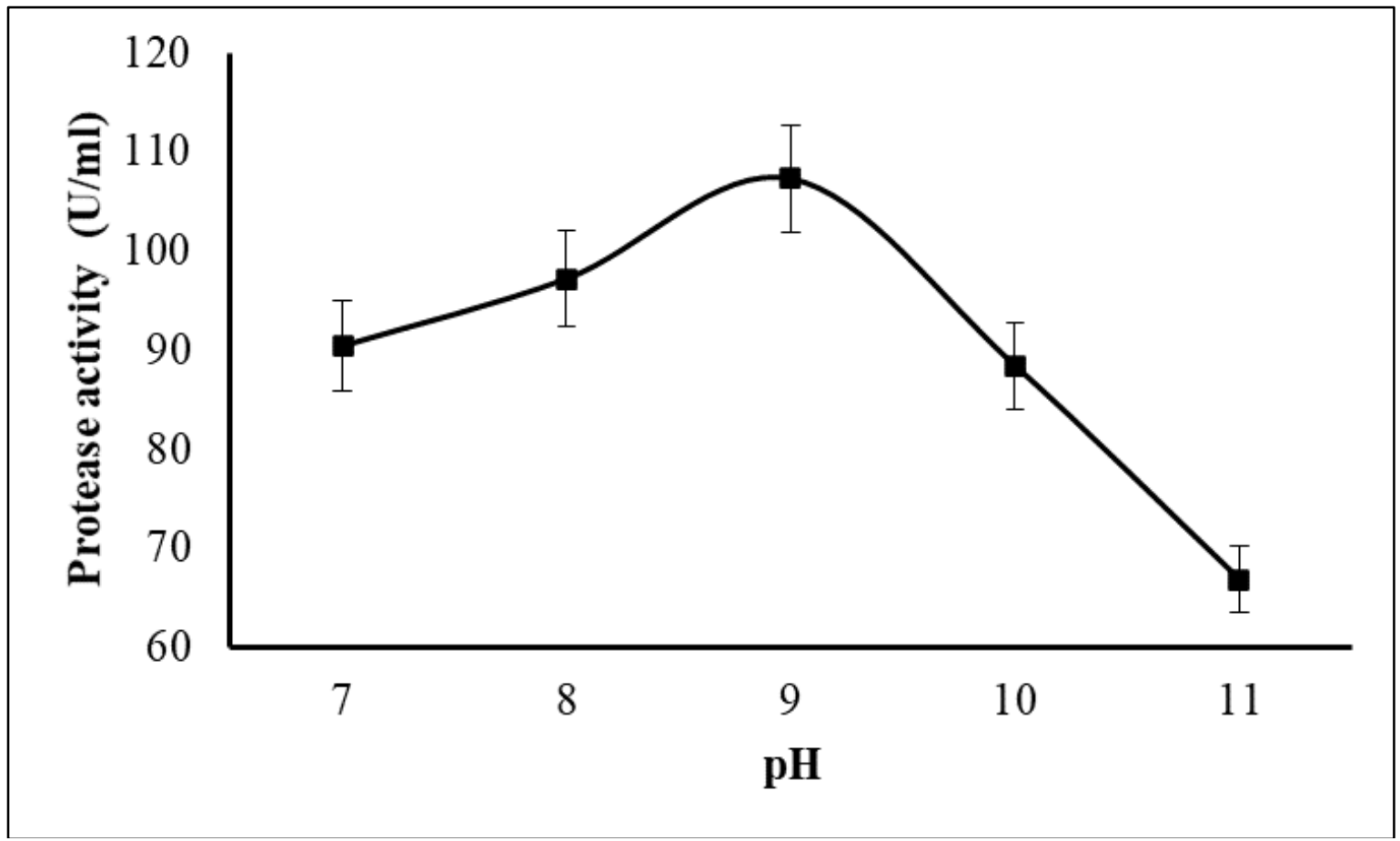

Fig 3: Effect of pH on alkaline protease activity of Staphylococcus cohnii N3 


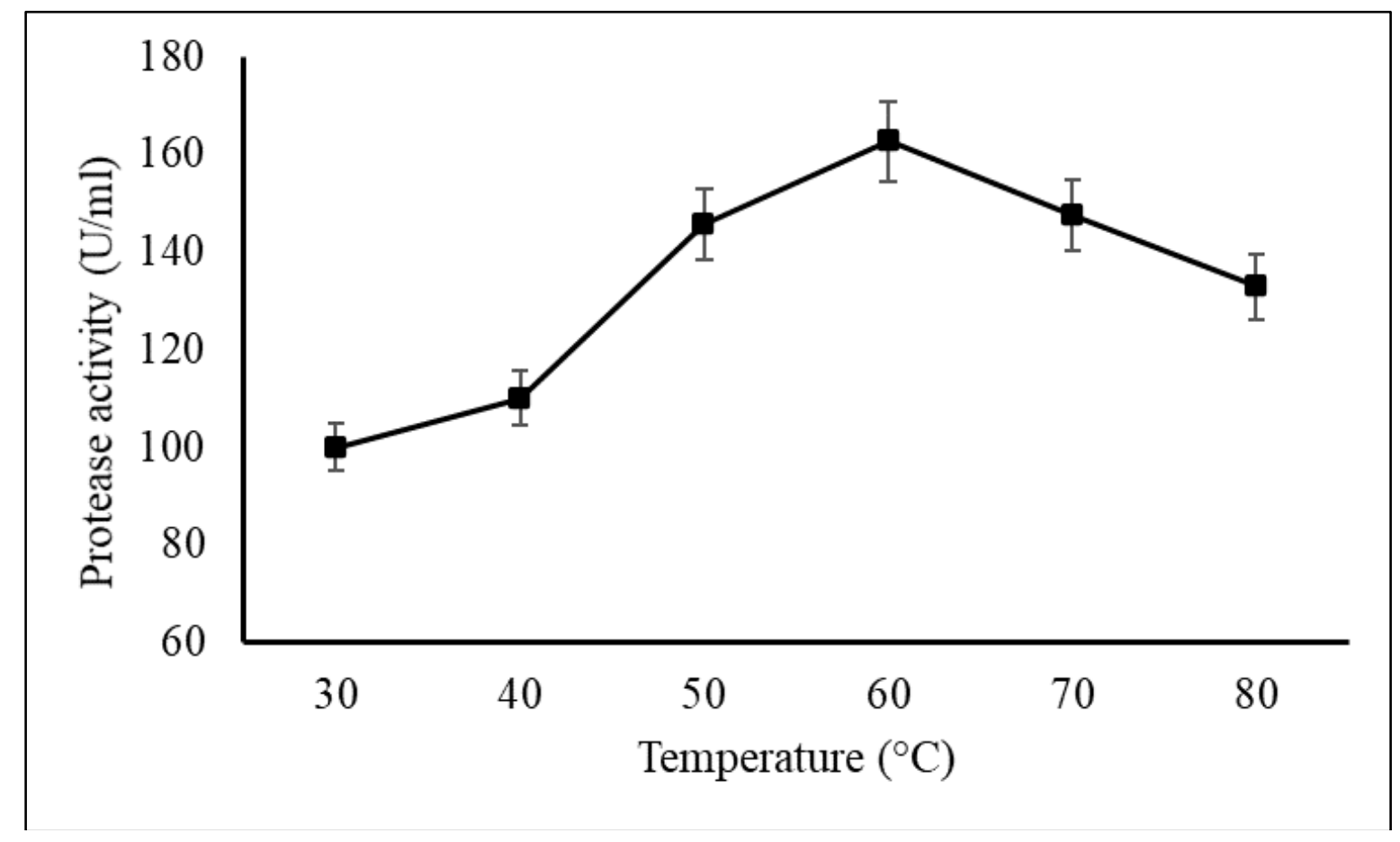

Fig 4: Effect of Temperature on alkaline protease activity of Staphylococcus cohnii N3

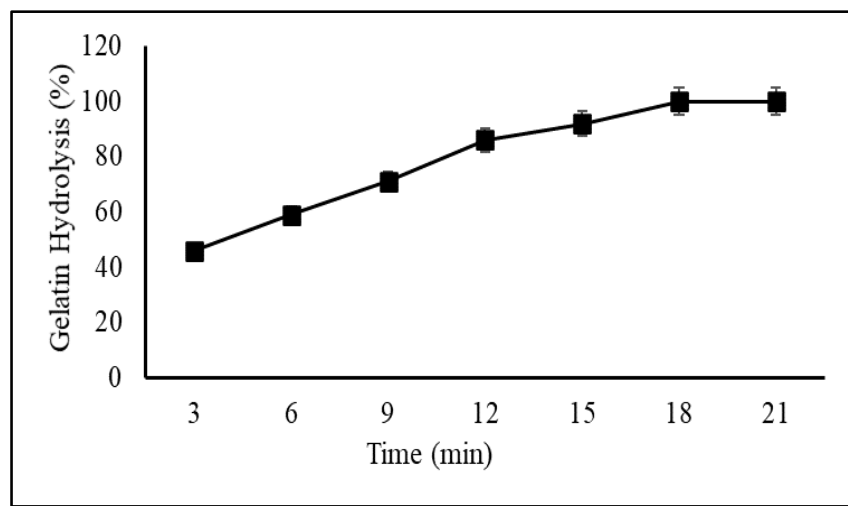

A

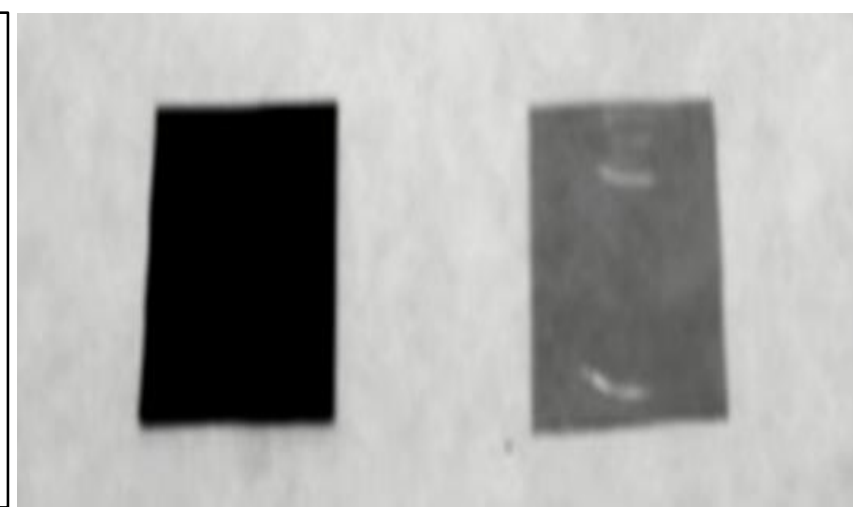

B

Fig. 5: Gelatin hydrolysis (a) and Decolorization of X-ray film (b) for Silver Recovery

\section{Conclusion}

The present investigation concluded that the increased protease activity of the selected isolate at high $\mathrm{pH}$ and temperature emphasis its promising implementation in various industries. In addition, the use of alkaline protease of Staphylococcus cohnii N3, an isolate of poultry farm has proven the efficacy of enzymatic method as an ecofriendly, cost effective approach for recovery of valuable silver from waste X-ray film thereby facilitate economical means for pollution.

\section{Acknowledgement}

We thank Management of the Standard Fireworks Rajaratnam College for women, Sivakasi, for the instrumentation facilities provided to successfully perform this research work.

\section{References}

1. Galarpe VRKR. Leopoldo GD Potential Recovery of Silver (Ag) from X-ray Fixer Waste by Alkaline Treatment. Engineering, Technology \& Applied Science Research. 2018;7(5):2094-2097.
2. Hossain F, Islam S, Kashem A, Osma KT, Zhou Y. Lead immobilization in soil using new hydroxyapatitelike compounds derived from oyster shell and its uptake by plant. Chemosphere. 2021;279: 130570https://doi.org/10.1016/j.chemosphere.2021.130 570.

3. Satyanarayana DNV, Chandra KR. Sliver Recovery from Waste X Ray Photographic Films by Electro Deposition. Journal of Advance Chemical Engineering. 2020;10:199. http://doi: 10.35248/20904568.20.10.199.

4. Guleria S, Walia A, Chauhan A, Shirkot CK. Production and eco friendly application of alkaline protease from Bacillus amyloliquifaciens sp Indian Journal of Biotechnology 2018;17:448-458.

5. Erku MD, Jabasingh SA, Yimam A. Silver Recovery from Waste X-Ray Photographic Films collected from Hospitals in Addis ababa. Journal of European Economic Association 2017;35:1-7.

6. Sharma M, Gat Y, Arya S, Kumar V, Panghal A, Kumar A. Industrial Biotechnology 152 Mary Ann Liebert 2019. http://doi: 10.1089/ind.2018.0032. 
7. Sundus H, Mukhtar H, Nawaz A. Industrial applications and production sources of serine alkaline proteases: a review. Journal of Bacteriology and Mycology. 2016;3(1):191-194.

8. Varia AD, Shukla VY, Tipre DR. Alkaline Protease - A Versatile Enzyme, International Journal of Research and Analytical Reviews 2019;6(2):208-219.

9. Akshantha J, Kumar BS, Shwetha H, Srivastava LH. Isolation and Screening of Alkaline protease producing Bacteria from fermented foods. International Journal of Current Advanced Research 2020;9(5):22218-22222.

10. Razzaq A, Shamsi S, Ali A, Ali Q, Sajjad M, Malik A, et al. Microbial protease Application. Frontiier in Biotecnology and Bioengineering. 2019; http://doi: 10.3389/fbioe.2019.00110.

11. Sarker1 PK, Talukdar SA, Deb P, Sayem SMB, Mohsina K. Optimization and partial characterization of culture conditions for the production of alkaline protease from Bacillus licheniformis P003. 2013;2:506 517.

12. Lowry OH, Rosebrough NJ, Farr AJ, Ramdall RJ. Protein measurement with folin phenol reagent. Journal of Biological Chemistry 1951;193:265-275.

13. Shankar S, More SV, Laxman RS. Recovery of Silver from waste X-ray film by Alkaline Protease from Conidiobolus coronatus Kathmandu University Journal of Science, Engineering and Technology 2010;6:60-69.

14. Rupali D. Screening and Isolation of Protease Producing Bacteria from Soil Collected from Different Areas of Burhanpur Region (MP) India. International, Journal of Current Microbiology and Applied Science 2015;4(8):597-606.

15. Hamdani S, Asstiyani N, Astriany D, Singgih M, Ibrahim S. Isolation and identification of proteolytic bacteria from pig sludge and protease activity determination. IOP Conf. Series: Earth and Environmental Science 230. IOP Publishing 2019; http://doi: 10.1088/1755-1315/230/1/012095.

16. Uttatree S, Charoenpanicha J. Purification and characterization of a harsh conditions-resistant protease from a new strain of Staphylococcus saprophyticus. Agriculture and Natural Resources 2018;52:16-23.

17. Chakraborty A, Karmakar S. Isolation of Protease Producing Bacteria from Soil and Characterization of the Protease. International Journal of Current Microbiology and Applied Sciences 2020;9(3):29742983.

18. Suleiman AD, Abdul Rahman NA, Yusof HM, Shariff FM, Yasid NA. Effect of Cultural Conditions on Protease Production by a Thermophilic Geobacillus thermoglucosidasius SKF4 isolated from Sungai Klah Hot Spring Park, Malaysia. Molecules 2020;25:http://doi: 10.3390/molecules25112609.

19. Patil NS, Kurhekar JV. Optimization of Protease Production by Bacillus isronensis Strain KD3 Isolated from Dairy Industry Effluent. Nature Environment and Pollution Technology 2020;19(3):1257-1264.

20. Sat EY, Yaman BN, Gedikli S, Çelik PA, Çabuk A. Heat and $\mathrm{pH}$ Stable Protease produced by a bacterium isolated from Fields with High Boron. Journal of Microbiology, Biotechnology and Food Science 2020;9(6):1047-1052.

21. Mushtaq H, Jehangir A, Ganai SA, Farooq S, Ahmad Ganai BA, Nazir R. Biochemical Characterization and
Functional Analysis of Heat Stable High Potential Protease of Bacillus amyloliquefaciens Strain HM48 from Soils of Dachigam National Park in Kashmir Himalaya. Biomolecules 2021;11:117. https://doi.org/10.3390/ biom11010117.

22. Karray A, Alonazi M, Horchani H, Bacha AB. A Novel Thermostable and Alkaline Protease produced from Bacillus stearothermophilus isolated from Olive Oil Mill Soils suitable to Industrial Biotechnology. Molecules 2021;(26):1139. https://doi.org/ 10.3390/ molecules26041139.

23. Akram M, Shafaat S, Bukhari DA, Rehman A. Characterization of a Thermostable Alkaline Protease from Staphylococcus aureus S-2 isolated from Chicken Waste. Pakistan Journal of Zoology 2014;46(4):11251132.

24. Chakrabarti S, Tiwari N, Khule P, Marar S, Kakkar S, Gupta AD. Isolation of protease producing bacteria from spoiled food and extraction of protease enzyme. International Journal of Applied Research 2018;4(7):141-146.

25. Saggu SK, Mishra PC. Characterization of thermostable alkaline proteases from Bacillus infantis SKS1 isolated from garden soil. 2017; https://doi.org/10.1371/ journal.pone. 0188724.

26. Gopalakrishnan D, Shanmugam VK. Thermo-Stable Alkaline Protease Purified from a Novel Endophyte Brevundimonas diminuta VKB1 hosted in Carica papaya L. - production enrichment Approach. Biointerface Research in Applied Chemistry. 2021;11(6):14372-14388.

27. Kumari P, Jandaik S, Batta S. Recovery of Silver from used X-Ray Films by Protease Isolated from Bacillus sp ATP-P5 and its Immobilization. Journal of Pure and Applied Microbiology 2015;9(2):371-375.

28. Parpalliwar JP, Patil PS, Patil ID, Deshannavar UB. Extraction of Silver from waste X-ray films using protease enzyme. International Journal of Advanced Biotechnology and Research 2015;6(2):220-226.

29. Al-Abdalall AH, Al-Khaldi EM. Recovery of silver from used X-ray film using alkaline protease from Bacillus subtilis sub sp. subtilis. African Journal of Biotechnology 2016;15(26):1413-1416. 